\title{
Regional and temporal variation of accumulation around NorthGRIP derived from ground-penetrating radar
}

\author{
Daniel STEINHAGE, ${ }^{1}$ Olaf EISEN, ${ }^{1}$ Henrik Brink CLAUSEN ${ }^{2}$ \\ ${ }^{1}$ Alfred-Wegener-Institut für Polar- und Meeresforschung, Columbusstrasse, D-27568 Bremerhaven, Germany \\ ${ }^{2}$ Niels Bohr Institutet for Astronomi, Fysik og Geofysik, Københavns Universitet, Juliane Maries Vej 30, \\ DK-2100 Copenhagen, Denmark
}

\begin{abstract}
During the summer of 2003, a ground-penetrating radar survey around the North Greenland Icecore Project (NorthGRIP) deep ice-core drilling site $\left(75^{\circ} 06^{\prime} \mathrm{N}, 42^{\circ} 20^{\prime} \mathrm{W} ; 2957 \mathrm{~m}\right.$ a.s.I.) was carried out using a shielded $250 \mathrm{MHz}$ radar system. The drill site is located on an ice divide, roughly $300 \mathrm{~km}$ north-northwest of the summit of the Greenland ice sheet. More than $430 \mathrm{~km}$ of profiles were measured, covering a $10 \mathrm{~km}$ by $10 \mathrm{~km}$ area, with a grid centered on the drilling location, and eight profiles extending beyond this grid. Seven internal horizons within the upper $120 \mathrm{~m}$ of the ice sheet were continuously tracked, containing the last 400 years of accumulation history. Based on the age-depth and density-depth distribution of the deep core, the internal layers have been dated and the regional and temporal distribution of accumulation rate in the vicinity of NorthGRIP has been derived. The distribution of accumulation shows a relatively smoothly increasing trend from east to west from $145 \mathrm{~kg} \mathrm{~m}^{-2} \mathrm{a}^{-1}$ to $200 \mathrm{~kg} \mathrm{~m}^{-2} \mathrm{a}^{-1}$ over a distance of $50 \mathrm{~km}$ across the ice divide. The general trend is overlain by small-scale variations on the order of $2.5 \mathrm{~kg} \mathrm{~m}^{-2} \mathrm{a}^{-1} \mathrm{~km}^{-1}$, i.e. around $1.5 \%$ of the accumulation mean. The temporal variations of the seven periods defined by the seven tracked isochrones are on the order of $\pm 4 \%$ of the mean of the last 400 years, i.e. at NorthGRIP $\pm 7 \mathrm{~kg} \mathrm{~m}^{-2} \mathrm{a}^{-1}$. If the regional accumulation pattern has been stable for the last several thousand years during the Holocene, and ice flow has been comparable to today, advective effects along the particle trajectory upstream of NorthGRIP do not have a significant effect on the interpretation of climatically induced changes in accumulation rates derived from the deep ice core over the last $10 \mathrm{kyr}$.
\end{abstract}

\section{INTRODUCTION}

The mass balance of an ice sheet is determined by net precipitation and loss of mass by outflow and melting (Paterson, 1994). While ice thickness and surface velocities can be evaluated by means of remote sensing (e.g. groundbased and airborne ice-penetrating radar (GPR) and satellite interferometry) the accumulation rate has to be measured by using samples taken from the ice sheet with snow pits, firn and ice cores. Therefore the accumulation measurements are less frequent than ice-thickness or surface velocity data (Giovinetto and others, 1990). For Greenland, for instance, only approximately 360 estimates of accumulation rate were available by 2001 (Bales and others, 2001). GPR has become a common tool for determining the structure of ice sheets and glaciers (e.g. Nereson and others, 2000; Richardson-Näslund, 2001; Frezzotti and others, 2002; Pälli and others, 2002). While low-frequency GPR is used to determine ice thickness and subglacial bed elevation, highfrequency GPR is used to reveal internal structure and layering of the upper part of ice sheets and glaciers. The velocity of the electromagnetic waves in ice can be determined by so-called common-midpoint measurements or by measuring the dielectrical properties of an ice core. By applying the velocity-depth function on the measured travel times, the depths of detected internal horizons can be tied to firn and ice cores (Hempel and others, 2000). As buried erosional surfaces due to absence of surface melting and wind erosion can be excluded in the investigated area around the North Greenland Icecore Project (NorthGRIP) site, the internal horizons are isochrones (Gudmandsen, 1975; Jacobel and Hodge, 1995; Eisen and others, 2004); this allows determination of the accumulation rates along GPR profiles. Mapping internal horizons allows a vast increase in accumulation rate data and makes it possible to assess the representativeness of the data obtained from snow pits and ice-core drill sites and to reveal regional variations. In order to study the local accumulation pattern around the NorthGRIP deep ice-core drill site in north-central Greenland (Fig. 1), a ground-based GPR survey was carried out in 2003 by the Alfred-Wegener-Institut (AWI). By tracking seven internal reflection horizons (IRHs) along all profiles, the temporal variations for seven periods were mapped over the investigated area.

\section{FIELD MEASUREMENTS}

The aim of the survey was to map the internal structure of the upper $100 \mathrm{~m}$ of ice sheet within a $10 \mathrm{~km}$ by $10 \mathrm{~km}$ rectangle around NorthGRIP. The area covered was extended by a set of GPR profiles extending $5 \mathrm{~km}$ further along, and $20 \mathrm{~km}$ further perpendicular to, the ice divide. The resulting 'butterfly'-shaped survey pattern is shown as white lines in Figure 2. The line spacing of the grid is $1 \mathrm{~km}$, with the $4 \mathrm{~km}$ line parallel to the ridge left out on both sides (Fig. 2 ). The surveyed area has been completed by a profile to NGT45, the end point of the AWI North Greenland traverse (Shuman and others, 2001). All measurements were carried out using a snowmobile equipped with global positioning system (GPS) for navigational purposes and geodetic measurements, towing a sledge with the operator, the GPR equipment and antennae. The total length of all profiles with GPS and GPR measurements is $430 \mathrm{~km}$. 


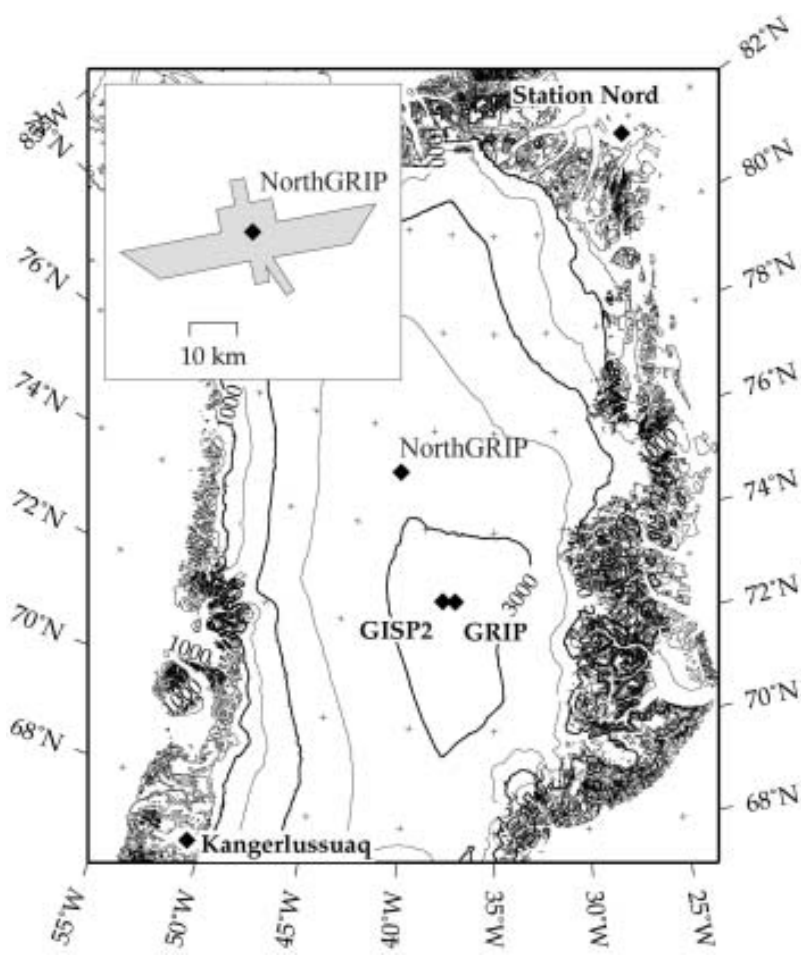

Fig. 1. Location map of NorthGRIP deep ice-core drill site and the survey area around NorthGRIP. The inset shows the investigated area around NorthGRIP.

\section{Kinematic GPS}

A Trimble 4000 SSI GPS receiver was operated at a sampling rate of $1 \mathrm{~Hz}$ for navigation as well as for determining surface topography along all GPR profiles with the antenna mounted on the towing snowmobile. For differential post-processing of the kinematic GPS data, a GPS reference station was established on the reference GPS point of the NorthGRIP camp site. The calculated surface heights were tied to this
Table 1. TWTs and depths of picked IRHs at NorthGRIP

\begin{tabular}{lcccc}
\hline IRH No. & TWT & Depth & Date & Interval \\
& ns & m & AD & years \\
\hline 1 & & & & \\
\hline & 155 & 16.5 & 1957 & 46 \\
3 & 280 & 29.0 & 1914 & 43 \\
4 & 410 & 42.0 & 1865 & 49 \\
5 & 545 & 55.0 & 1811 & 44 \\
6 & 680 & 66.5 & 1758 & 53 \\
7 & 905 & 86.5 & 1662 & 96 \\
& 1055 & 99.5 & 1597 & 65 \\
\hline
\end{tabular}

reference. The resulting surface topography based on all GPS observations interpolated onto a $1^{\prime}$ by $0.25^{\prime}$ (approximately $460 \mathrm{~m}$ by $460 \mathrm{~m}$ ) grid is shown in Figure 2. Within the $450 \mathrm{~km}^{2}$ area covered by the investigations, no height variation above $20 \mathrm{~m}$ was found. Along the ice divide running north-northwest the surface slope is $0.8 \%$, and perpendicular to the ridge $0.5 \%$.

\section{Ground-penetrating radar}

The GPR survey was performed with a commercial RAMAC radar set (Malå Geoscience, Sweden) with shielded antennae operating at a center frequency of $250 \mathrm{MHz}$. The traces were recorded in a 1500 ns time window with 1024 samples and eight-fold horizontal stacking at $1 \mathrm{~m}$ intervals using an odometer. The recorded two-way travel times (TWTs) have been converted to depths based on the density-depth information obtained from a shallow ice core drilled in the immediate vicinity of the NorthGRIP drill site. First analysis of the internal structure included mapping of seven continuous IRHs, the deepest of which is located at a TWT of 1055 ns near NorthGRIP (Fig. 3). TWTs and depths of all seven picked IRHs at NorthGRIP are summarized in Table 1.

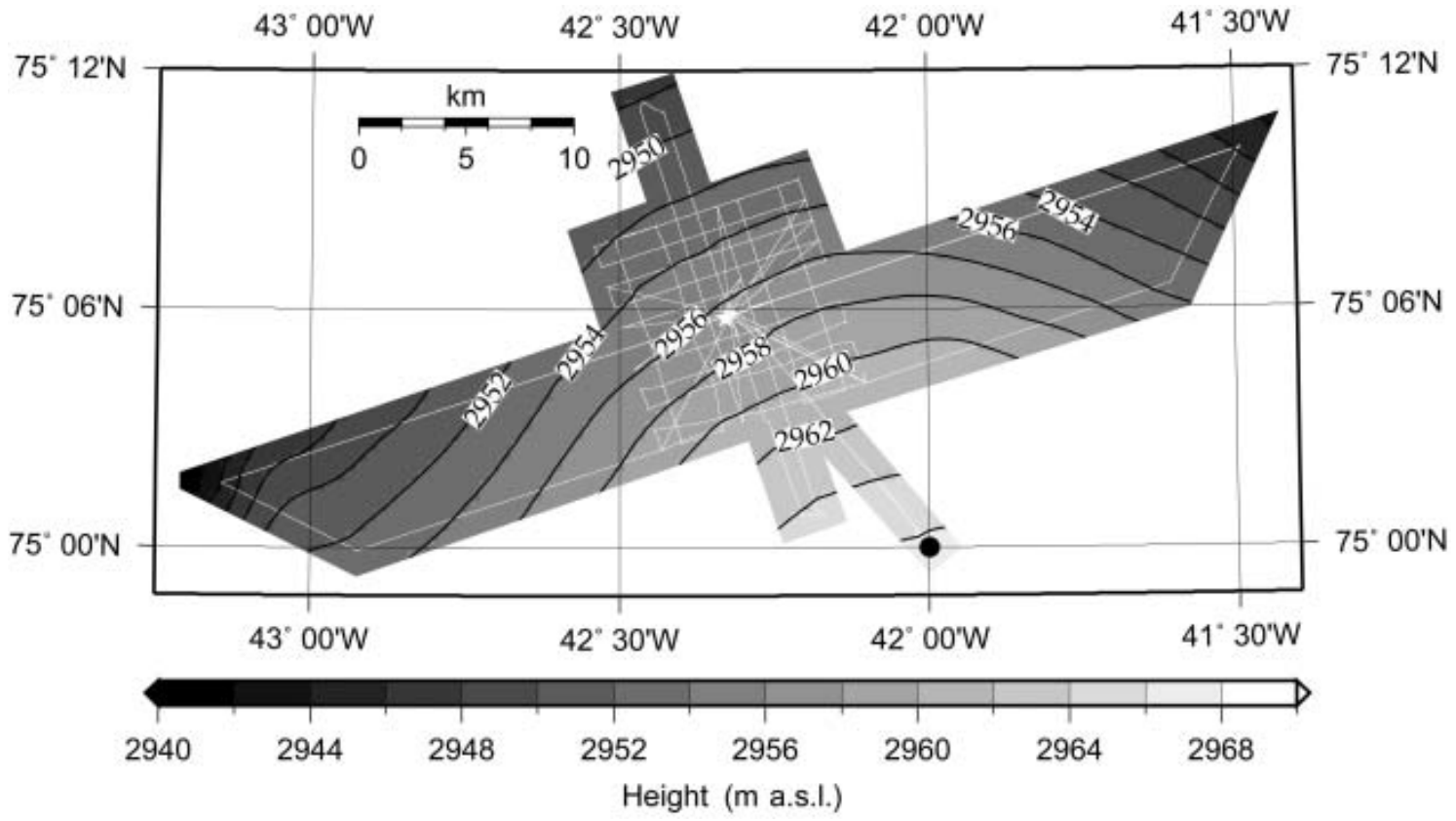

Fig. 2. Survey layout (white lines) and surface topography from kinematic post-differential GPS around NorthGRIP (white star). The black dot marks the drill site NGT 45 . The contour line spacing is $2 \mathrm{~m}$. 


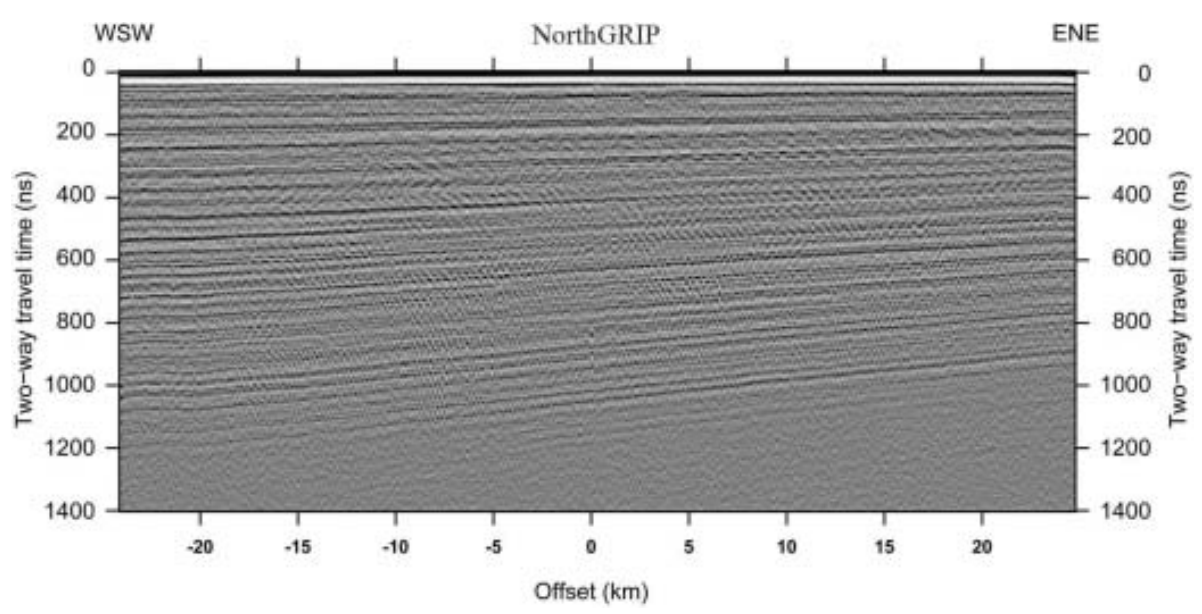

Fig. 3. GPR profile obtained with $250 \mathrm{MHz}$ shielded antennae perpendicular to the ice divide across NorthGRIP. The profile runs from westsouthwest to east-northeast over a distance of $50 \mathrm{~km}$. NorthGRIP is located in the center; the offset is calculated relative to the drill site. The grayscale indicates strength of the signal envelope.

Reflector travel times increase steadily from east-northeast to west-southwest, perpendicular to the ice divide, by $40 \%$ over a distance of $50 \mathrm{~km}$. Parallel to the ice flow the reflector travel times are nearly constant. The internal structure shows hardly any undulations, not surprisingly as the basal topography is known to be very flat (Göktaş, 1999; Nixdorf and Göktaş, 2001). The observed pattern is therefore most likely caused by a known variation of the accumulation rate across the ice divide, rather than by significant changes of the wave-speed-depth profiles or other dynamical effects. The GPR dataset is therefore used to derive the small-scale spatial variation of accumulation over the past 400 years.

\section{ACCUMULATION RATE}

The distribution of accumulation requires the dating of each IRH and calculation of cumulative mass. From dating of

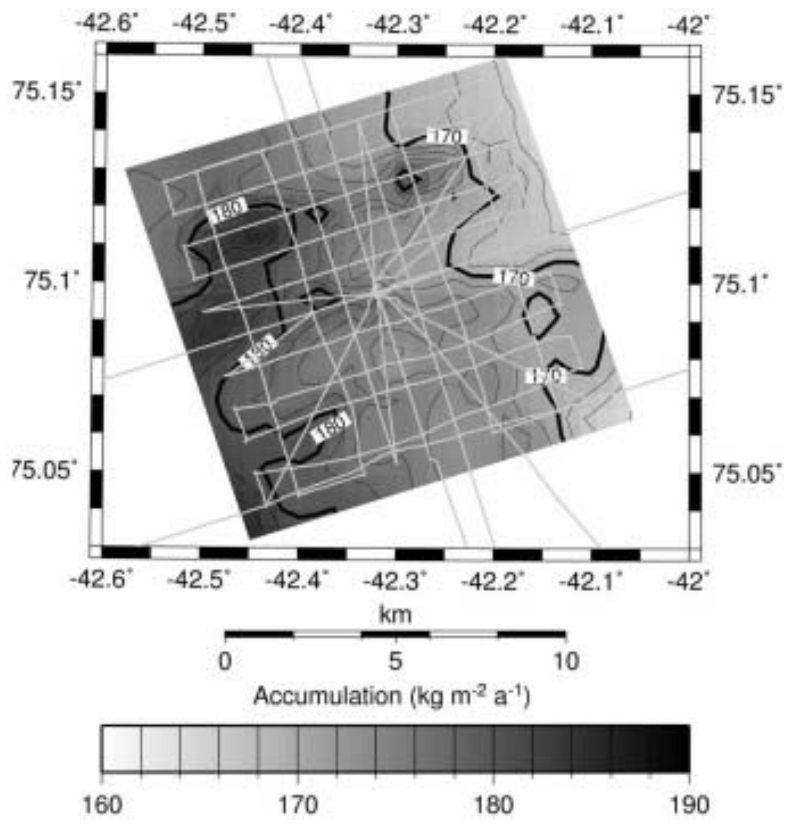

Fig. 4. Regional accumulation pattern around NorthGRIP derived from IRH-1, the shallowest tracked IRH, for the period 1953-2003. Contour line spacing is $2 \mathrm{~kg} \mathrm{~m}^{-2} \mathrm{a}^{-1}$. volcanic peaks in the electrical conductivity record along the shallow ice core, an age-depth function is available. At the drill site, each reflector is attributed an age from the shallow core. Integration of density yields the cumulative mass. As the horizontal distribution of density with depth is fairly constant across the region of interest, we assume that the cumulative mass-depth distribution is uniform along all GPR profiles, too. The accumulation rate along the profiles for different time intervals is derived from adjacent pairs of IRHs by calculating the ratio of their difference in cumulative mass and difference in age. The resulting time intervals vary between 43 and 96 years. Note that although the resulting accumulation rate is expressed in units of mass per unit area and year, the values represent a low-pass filtered average. The uncertainty of accumulation rate depends on the dating of the IRHs, conversion from travel time to depth, and calculation of cumulative mass. From crossover point analyses within the grid, we found that a typical uncertainty of $5 \mathrm{~ns}$ in travel time, corresponding to roughly $0.5 \mathrm{~m}$ in depth, results in a relative accumulation rate uncertainty of $6 \mathrm{~kg} \mathrm{~m}^{-2} \mathrm{a}^{-1}$ on average. Including dating uncertainty, the estimated total uncertainty in accumulation is around $\pm 8-9 \mathrm{~kg} \mathrm{~m}^{-2} \mathrm{a}^{-1}$ for values close to the GPR profiles. This corresponds to some $5 \%$ of the mean accumulation rate at NorthGRIP of $171 \mathrm{~kg} \mathrm{~m}^{-2} \mathrm{a}^{-1}$ for the complete period under consideration, AD 1597-2003.

\section{Spatial distribution}

Gridding of accumulation values along the profiles results in a distribution of accumulation around NorthGRIP. As an example, the areal variation of the accumulation rate for the most recent period, 1957-2003, is shown in Figure 4. Within the grid, accumulation rate decreases perpendicular to the ice divide in the west-southwest to east-northeast direction from $180 \mathrm{~kg} \mathrm{~m}^{-2} \mathrm{a}^{-1}$ to $170 \mathrm{~kg} \mathrm{~m}^{-2} \mathrm{a}^{-1}$ over $10 \mathrm{~km}$. As would be expected from the distribution of IRH travel times, the accumulation parallel to the topographic divide is almost constant. Small-scale variations in accumulation are in general in the order of $2-3 \mathrm{~kg} \mathrm{~m}^{-2} \mathrm{a}^{-1} \mathrm{~km}^{-1}$. Larger gradients of up to $8 \mathrm{~kg} \mathrm{~m}^{-2} \mathrm{a}^{-1} \mathrm{~km}^{-1}$ are observed over a distance of $1 \mathrm{~km}$ about $4 \mathrm{~km}$ directly north and east of the drill site. As these small-scale variations are around $5 \%$ of the mean accumulation at NorthGRIP, they are in the same order of 


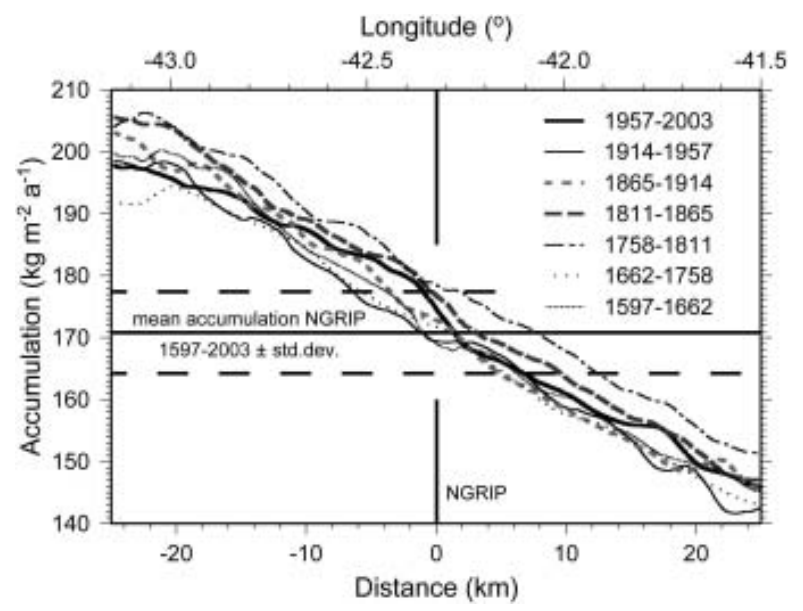

Fig. 5. Accumulation distribution for seven periods (see legend) perpendicular to the ice divide along GPR profile shown in Figure 3. The bar in the center marks the position of NorthGRIP and shows this variation as well as the temporal average.

magnitude as the uncertainty, and have to be considered with care. Accumulation maps for the other time interval show the same characteristics, with slightly different absolute values, but the same gradients, implying that the accumulation pattern has been constant for the last 400 years.

\section{Comparison of temporal and spatial changes}

We analyze the variations of accumulation along the $50 \mathrm{~km}$ long central profile perpendicular to the ice divide to investigate the temporal character of spatial changes in accumulation. For all seven time intervals, the accumulation decreases at $1.1 \mathrm{~kg} \mathrm{~m}^{-2} \mathrm{a}^{-1} \mathrm{~km}^{-1}$ on average over the whole profile (Fig. 5). However, the mean accumulation at NorthGRIP for each period varies between 168 and $179 \mathrm{~kg} \mathrm{~m}^{-2} \mathrm{a}^{-1}$. The temporal variation of accumulation can be directly calculated from the original ice-core record over the last 400 years. Applying a 25 year running mean filter to reduce noise, the resulting $1 \sigma$ level of standard deviation is $6.5 \mathrm{~kg} \mathrm{~m}^{-2} \mathrm{a}^{-1}$ for the period 1597-2003.

\section{DISCUSSION AND CONCLUSIONS}

Based on a GPR survey, the structure of the upper $120 \mathrm{~m}$ of the ice sheet in the vicinity of the NorthGRIP deep ice-core drill site has been mapped. Dating of seven continuous IRHs in conjunction with data from a shallow core allowed us to evaluate the small-scale variations of the accumulation rate around the drill site. As the surface velocity at NorthGRIP is low $\left(\sim 1 \mathrm{ma}^{-1}\right.$ in the direction of the ice divide, northnorthwest (Hvidberg and others, 2002)) and the strain rates are small $\left(\varepsilon_{1}=-0.4 \times 10^{-5} \mathrm{a}^{-1}, \varepsilon_{2}=7.1 \times 10^{-5} \mathrm{a}^{-1}\right.$, and $\varepsilon_{z}=7.36 \times 10^{-5} \mathrm{a}^{-1}$ (Hvidberg and others, 2002)), advection of ice parcels through stationary small-scale spatial variations in accumulation has a very small effect on values derived from ice cores compared to temporal changes. For instance, whereas the typical temporal changes over 25 years amount to almost $4 \%$ of the accumulation mean, transition of a particle trajectory through the largest accumulation anomaly observed in our data $(4 \mathrm{~km}$ north of NorthGRIP, about $1 \mathrm{~km}$ wide) will last around 1000 years and result in an apparent decrease in accumulation of $<2 \%$ over the same period. This is an advantage of the NorthGRIP drill site, in contrast to other drilling locations (e.g. South Pole (Hamilton, 2004) or Dronning Maud Land, Antarctica (Eisen and others, 2005)). The GPR survey also reveals that the accumulation rate of $171 \mathrm{~kg} \mathrm{~m}^{-2} \mathrm{a}^{-1}$ for NorthGRIP is a representative value along the ice divide for the mapped area. Together with the clear west-to-east decrease in accumulation, our results are in agreement with the general trend in accumulation distribution as shown in the accumulation map of Bales and others (2001). Furthermore we conclude that the accumulation pattern did not change over the considered time period of 400 years, i.e. the spatial trend has been stable and the mean accumulation merely varied over time. If this has been the case for the last several thousand years during the Holocene and ice flow has been comparable to today, advective effects along the particle trajectory upstream of NorthGRIP do not have a significant effect on the interpretation of climatically induced changes in accumulation rates derived from the deep ice core over the last $10 \mathrm{kyr}$.

To investigate the influence of local variations in accumulation during the last ice age, accumulation should be analyzed from high-resolution GPR profiles along the upstream particle trajectories.

\section{ACKNOWLEDGEMENTS}

We thank the NorthGRIP team for their hospitality and support in the field. Thanks are also due to C. Wesche and S. Schober for data handling.

\section{REFERENCES}

Bales, R.C., J.R. McConnell, E. Mosley-Thompson and B. Csatho. 2001. Accumulation over the Greenland ice sheet from historical and recent records. J. Geophys. Res., 106(D24), 33,813-33,825.

Eisen, O., U. Nixdorf, F. Wilhelms and H. Miller. 2004. Age estimates of isochronous reflection horizons by combining ice core, survey, and synthetic radar data. J. Geophys. Res., 109(B4), B04106. (10.1029/2003JB002858.)

Eisen, O., W. Rack, U. Nixdorf and F. Wilhelms. 2005. Characteristics of accumulation around the EPICA deep-drilling site in Dronning Maud Land, Antarctica. Ann. Glaciol., 41, 41-46.

Frezzotti, M., S. Gandolfi, F. La Marca and S. Urbini. 2002. Snow dunes and glazed surfaces in Antarctica: new field and remotesensing data. Ann. Glaciol., 34, 81-88.

Giovinetto, M.B., N.M. Waters and C.R. Bentley. 1990. Dependence of Antarctic surface mass balance on temperature, elevation, and distance to open ocean. J. Geophys. Res., 95(D4), 3517-3531.

Göktaş, F. 1999. Ergebnisse der Untersuchung des grönländischen Inlandeises mit dem elektromagnetischen Reflexionsverfahren in der Umgebung von NGRIP. Ber. Polarforsch. Rep./Pol. Res. 336.

Gudmandsen, P. 1975. Layer echoes in polar ice sheets. J. Glaciol., 15(73), 95-101.

Hamilton, G.S. 2004. Topographic control of regional accumulation rate variability at South Pole and implications for ice-core interpretation. Ann. Glaciol., 39, 214-218.

Hempel, L., F. Thyssen, N. Gundestrup, H.B. Clausen and H. Miller. 2000. A comparison of radio-echo sounding data and electrical conductivity of the GRIP ice core. J. Glaciol., 46(154), 369-374.

Hvidberg, C.S., K. Keller and N.S. Gundestrup. 2002. Mass balance and ice flow along the north-northwest ridge of the Greenland ice sheet at NorthGRIP. Ann. Glaciol., 35, 521-526.

Jacobel, R.W. and S.M. Hodge. 1995. Radar internal layers from the Greenland summit. Geophys. Res. Lett., 22(5), 587-590.

Nereson, N.A., C.F. Raymond, R.W. Jacobel and E.D. Waddington. 2000. The accumulation pattern across Siple Dome, West 
Antarctica, inferred from radar-detected internal layers. J. Glaciol., 46(152), 75-87.

Nixdorf, U. and F. Göktaş. 2001. Spatial depth distribution of the subglacial bed and internal layers in the ice around NGRIP, Greenland, derived with airborne RES. J. Appl. Geophys., 47(3-4), 175-182.

Pälli, A. and 6 others. 2002. Spatial and temporal variability of snow accumulation using ground-penetrating radar and ice cores on a Svalbard glacier. J. Glaciol., 48(162), 417-424.
Paterson, W.S.B. 1994. The physics of glaciers. Third edition. Oxford, etc., Elsevier.

Richardson-Näslund, C. 2001. Spatial distribution of snow in Antarctica and other glacier studies using ground-penetrating radar. (PhD thesis, Stockholm University.)

Shuman, C.A., D.H. Bromwich, J. Kipfstuhl and M. Schwager. 2001. Multiyear accumulation and temperature history near the North Greenland Ice Core Project site, north central Greenland. J. Geophys. Res., 106(D24), 33,853-33,866. 